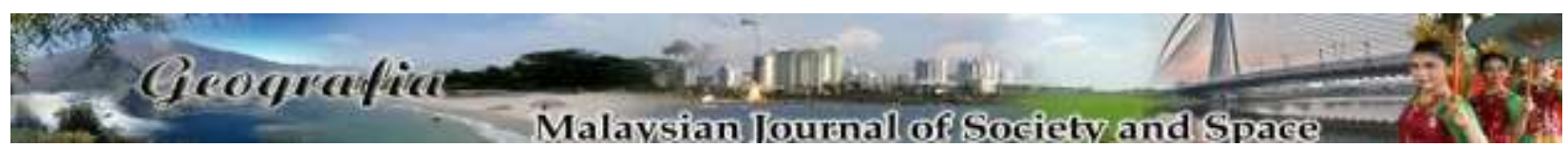

\title{
Penilaian keberkesanan terowong SMART Kuala Lumpur dalam menghalang banjir kilat
}

\author{
Siti Hasniza Muhammad Arshad ${ }^{1}$, Asnor Muizan Hj. Ishak ${ }^{2}$, Nurfashareena Muhamad ${ }^{1}$, \\ Joy Jacqueline Pereira ${ }^{1}$ \\ ${ }^{1}$ Pusat Kajian Bencana Asia Tenggara (SEADPRI-UKM), \\ Institut Alam Sekitar dan Pembangunan, Universiti Kebangsaan Malaysia \\ ${ }^{2}$ Pengurusan Sumber Air dan Hidrologi, Jabatan Pengairan dan Saliran (JPS), \\ Wilayah Persekutuan Kuala Lumpur, Malaysia \\ Correspondence: Nurfashareena Muhamad (email: fasha@ukm.edu.my)
}

Received: 28 February 2020; Accepted: 16 July 2020; Published: 28 August 2020

\begin{abstract}
Abstrak
Tujuan utama pembinaan Terowong SMART adalah untuk mengurangkan kejadian banjir kilat di pusat bandar Kuala Lumpur. Banjir kilat di pusat bandar menyebabkan kerugian ekonomi dan menganggu aktiviti komersial bandar. Objektif kajian ini adalah untuk mengkaji keberkesanan Terowong SMART dalam menangani masalah kejadian banjir kilat. Kekerapan dan taburan banjir kilat di Kuala Lumpur dari 1984 hingga 2017 serta liputan kawasan Terowong SMART dianalisis dengan menggunakan Sistem Maklumat Geografi (GIS). Hasil kajian menunjukkan bahawa selepas Terowong SMART mula berfungsi pada tahun 2007, kejadian banjir kilat menurun, tetapi sejak 2010, kejadian air bertakung telah menjadi berleluasa. Hanya 7 kejadian banjir kilat telah direkodkan sejak pembukaan Terowong SMART tetapi di antara 2010 dan 2017, sebanyak 83 kejadian air bertakung telah dilaporkan. Terowong SMART telah memainkan peranan yang penting untuk menghalang lebih banyak kejadian banjir kilat daripada berlaku di pusat Bandaraya Kuala Lumpur. Walau bagaimanapun, masalah air bertakung harus ditangani secara holistik melalui perancangan yang berasaskan kepada pendekatan ekologi seperti yang digunapakai dalam pembangunan bandar raya sponge (sponge city development).
\end{abstract}

Kata kunci: air bertakung, banjir kilat, GIS, Kuala Lumpur, pencegahan bencana, Terowong SMART 
GEOGRAFIA Online ${ }^{\mathrm{TM}}$ Malaysian Journal of Society and Space 16 issue 3 (184-200)

(C) 2020, e-ISSN 2682-7727 https://doi.org/10.17576/geo-2020-1603-14

\title{
Assessing Effectiveness of Kuala Lumpur SMART Tunnel for Flood Prevention
}

\begin{abstract}
The main purpose of the SMART Tunnel is to reduce flash floods in the city centre of Kuala Lumpur. Flash floods have caused economic loss and interrupted urban commercial activities. This study analyses the effectiveness of the SMART Tunnel in preventing flash floods in the city centre. The frequency and distribution of flash floods from 1984 to 2017 as well as spatial coverage of the SMART Tunnel are analysed using Geographic Information System (GIS). The results show that after the SMART Tunnel started operations in 2007, the incidence of flash floods reduced, but since 2010, water ponding has become prevalent. Only 7 cases of flash floods were recorded after the SMART Tunnel was operational but between 2010 and 2017, a total of 83 water ponding incidents were reported. The SMART Tunnel has played a significant role in preventing further flash floods in the city center of Kuala Lumpur. However, the problem of water ponding should be addressed holistically through planning based on ecological approaches such as in sponge city development.
\end{abstract}

Keywords: water ponding, flash flood, GIS, Kuala Lumpur, disaster prevention, SMART Tunnel

\section{Pengenalan}

Daya tahan bandar telah berkembang secara konseptual dengan pelbagai tafsiran di seluruh disiplin polisi, amalan dan penyelidikan. Sedekad analisis terhadap literatur ketahanan bandar telah menunjukkan penerapan skop ketahanan bandar merangkumi lima bidang penyelidikan; perubahan iklim, perancangan bandar, masyarakat bandar, tenaga dan bencana (Potter \& Vilcan, 2020; Ribeiro \& Goncalves, 2019;). Fenomena perubahan iklim seiring dengan peningkatan aktiviti pembangunan yang pesat menjurus kepada cabaran besar dalam perancangan dan pengurusan kawasan bandar. Beberapa kajian terdahulu menunjukkan bahawa fenomena perubahan iklim berupaya mengubah kitaran hidrologi dan meningkatkan kebarangkalian berlakunya peristiwa cuaca ekstrim seperti banjir serta kemarau (Bates et al., 2008; Bertilsson et al., 2019; Dayon et al., 2018). Banjir menyebabkan berbilion ringgit kerosakan setiap tahun dan risiko banjir dijangka akan semakin meningkat berikutan perkembangan sosio-ekonomi dan perubahan iklim (Ward et al., 2017).

Banjir sungai (banjir fluvial) dan banjir kilat merupakan dua jenis banjir yang sering membawa mudarat. Ciri utama yang membezakan di antara kedua-dua kategori banjir ini adalah masa yang diambil untuk tahap air banjir untuk kembali ke tahap normal dari paras puncak. Banjir kilat mengambil masa beberapa jam untuk kembali ke tahap ekspresi normal berbanding dengan banjir sungai yang kadangkala mengambil masa sehingga sebulan untuk turun ke tahap normal (Baharuddin et al., 2012; Noorazuan, 2006). Sejak kebelakangan ini, banjir pluvial atau air bertakung (water ponding) semakin menular khususnya di kawasan bandar. Banjir pluvial dikaitkan dengan intensiti hujan setempat yang tinggi dan bersifat jangka pendek iaitu kurang daripada sejam. Kejadian ini sering berlaku di atas jalan raya dan boleh menyebabkan kesesakan lalu lintas. Ianya berlaku kerana kadar air yang jatuh semasa hujan melebihi kadar penyusupan 
GEOGRAFIA Online ${ }^{\mathrm{TM}}$ Malaysian Journal of Society and Space 16 issue 3 (184-200)

(C) 2020, e-ISSN 2682-7727 https://doi.org/10.17576/geo-2020-1603-14

permukaan disebabkan oleh sistem saliran bandar yang kurang cekap dan tidak mencukupi untuk menampung keamatan hujan (Bulti \& Abebe, 2020; Lwe \& Arnbjerg-Nielsen, 2020; Rubinato et al., 2019; Tiza et al., 2016; Van Der Sterren et al., 2007). Keadaan air bertakung juga berlaku jika longkang atau laluan air tersumbat disebabkan sampah sarap yang dibawa oleh air atau tertutup akibat kerja-kerja pembinaan yang dijalankan di kawasan sekitar. Banjir pluvial sangat sukar diramalkan dan lazimnya mencabar pengurusan bandar.

Banjir merupakan fenomena yang biasa di negara beriklim tropika seperti Malaysia (Chan, 1995; Mohamad Yusoff et al., 2018; Sani et al., 2014). Banjir di Malaysia sering dikelaskan sebagai banjir bermusim (monsun), banjir kilat dan banjir pasang-surut (JPS, 2000; JPS, 2017). Selain itu, banjir juga boleh diterangkan berdasarkan lokasi, ciri, punca, masa apabila banjir berlaku dan tempoh banjir berlaku (JPS, 2017). Antara bencana banjir yang paling serius berlaku di Malaysia adalah kejadian banjir monsoon di pantai timur Semenanjung Malaysia pada akhir tahun 2014 dan awal tahun 2015 yang mengakibatkan 200,000 orang terjejas dan 21 orang terbunuh. Mangsa-mangsa banjir ini mengambil masa lebih daripada setahun untuk pulih dan kembali ke kehidupan normal mereka. Insiden banjir yang digelar Banjir Kuning ini mengakibatkan sebanyak 2,374 rumah musnah secara total. Jumlah terbesar rumah yang musnah ialah di Kuala Krai sebanyak 1,850 buah, Gua Musang 406 buah, Machang 51 buah, Tanah Merah 38 buah, Kota Bharu 18 buah, Tumpat 11 buah dan lebih banyak di jajahan lainnya (Buletin Darulnaim, 2015). Ini adalah satu nilai kerosakan yang besar. Sementara itu, banjir kilat di Pulau Pinang yang berlaku pada 5 November 2017 menyebabkan negeri tersebut lumpuh selepas berpuluh-puluh jalan ditutup dan ratusan rumah tenggelam akibat hujan lebat yang turun lebih daripada 15 jam (Shamsul, 2017) dan mencatatkan paras tertinggi iaitu $372 \mathrm{~mm} / \mathrm{jam}$ (Buletin Mutiara, 2017). Banjir kilat tersebut mengakibatkan tujuh kematian dan kerosakan yang teruk terhadap kediaman, perniagaan, organisasi dan kenderaan.

Kuala Lumpur tidak terkecuali daripada dilanda masalah banjir. Fenomena banjir terawal yang melanda bandar ini telah direkodkan pada tahun 1926 yang dikenali sebagai Bah Besar 1926. Seterusnya, pada tahun 1971 bandar ini turut mengalami kejadian banjir besar yang berlangsung selama lima hari dan menyebabkan kerosakan yang serius (Abdullah, 2004). Beberapa kejadian banjir besar lain di Kuala Lumpur termasuklah pada 30 April 2000, 26 April 2001, 29 Oktober 2001, 11 Jun 2002, 10 Jun 2003 dan 10 Jun 2007. Kejadian-kejadian tersebut telah menyebabkan kerosakan (Bhuiyan et al., 2018; Diya et al., 2014) terhadap harta benda, kehilangan nyawa, gangguan trafik seterusnya memberi kesan kepada aktiviti sosio-ekonomi dan imej Kuala Lumpur sebagai ibu negara Malaysia (Aziz, 2013). Aktiviti perbandaran yang pesat berserta dengan sistem saliran bandar yang kurang cekap menyebabkan Kuala Lumpur seringkali mengalami banjir kilat (JPS, 2017; Kong et al., 2010; Nuhu \& Ali, 2017). Terdahulu, Hashim dan Ahmad (2007) turut mengetengahkan punca kekerapan banjir kilat di bandaraya ini adalah disebabkan oleh pertambahan kawasan tepu bina dan pengurangan litupan tumbuhan. Ini telah menyebabkan pengurangan kawasan telap air yang menyebabkan aliran air hujan terus mengalir ke saliran dan menyebabkan peningkatan kapasiti air ke saliran. Namun, saliran sedia ada tidak bertambah seiring dengan pertambahan kawasan pembangunan di bandar. Hal ini terlihat menjadi penyebab khusus dari fenomena banjir kilat di Kuala Lumpur. JPS (1999) juga melaporkan bahawa pembangunan infrastruktur kota di sepanjang Sungai Kelang telah dikenalpasti sebagai penyebab utama meningkatnya kekerapan banjir kilat di Lembangan Sungai Kelang. Situasi ini bertambah buruk apabila sisa domestik dibuang ke dalam sistem longkang dan sungai yang mengakibatkan saliran tersumbat. Selain campur tangan manusia yang menyumbang kepada perubahan rupa bumi faktor semula jadi yang melibatkan aspek fizikal 
GEOGRAFIA Online ${ }^{\mathrm{TM}}$ Malaysian Journal of Society and Space 16 issue 3 (184-200)

(C) 2020, e-ISSN 2682-7727 https://doi.org/10.17576/geo-2020-1603-14

bumi seperti litologi dan pengaruh iklim seperti hujan lebat turut menyumbang kepada kejadian banjir di Kuala Lumpur ( JPS, 2017; Samsuri et al., 2018; Sani et al., 2014).

Susulan daripada banjir besar yang berlaku pada tahun 1971, kerajaan telah mengambil beberapa langkah positif untuk menangani masalah ini. Antara langkah tersebut adalah Pengurusan Banjir Bersepadu yang menggariskan pelaksanaan langkah struktural dan langkah bukan struktural, penubuhan sistem ramalan banjir yang merangkumi kajian lembangan sungai dan penyediaan pelan induk saliran untuk bandar utama serta penubuhan rangkaian stesen pengumpulan data hidrologi dan banjir di seluruh negara (Chong Wing, 2016). Salah satu langkah yang diambil di Kuala Lumpur adalah pembinaan sebuah terowong pintar yang membolehkan air banjir dialirkan keluar daripada pusat bandar. Pembinaan terowong Pengurusan Air Ribut dan Terowong Jalan Raya atau lebih dikenali sebagai Stormwater Management and Road Tunnel atau SMART telah dimulakan pada 25 November 2003 (Mohamad Khairul Nizam et al., 2014). Objektif utama SMART adalah untuk mengurangkan masalah banjir di pusat Bandaraya Kuala Lumpur akibat air ribut dari kawasan tadahan Klang-Ampang. Selain itu, SMART juga memberi manfaat tambahan dalam meredakan kesesakan lalu lintas di pintu masuk utama selatan (TUDM di Sg. Besi) ke pusat bandar (Pusat Kawalan SMART, 2016). Penggunaan terowong pintar bagi mengatasi masalah banjir turut digunapakai di negara Eropah seperti Paris dan Marseilles (Nordmark, 2002), Chaophraya Basin, Thailand (Tunnel, 2012) serta di Jepun (Zolbert \& Alex, 2012).

Sejak mula beroperasi, Terowong SMART ini didapati dapat mengelakkan kejadian banjir kilat berlaku di Kuala Lumpur. Namun, kesimpulan tersebut dicapai berdasarkan kepada tahap pengunaan terowong tersebut dan bukannya berdasarkan bukti empirikal. Justeru, kajian ini bertujuan untuk menilai keberkesanan Terowong SMART dalam menangani masalah banjir. Selain itu, hubungkait mod operasi Terowong dengan intensiti hujan bagi mengesahkan samada parameter ini mewakili kemungkinan kejadian banjir kilat.

\section{Terowong SMART}

Terowong SMART sering disalah anggap sebagai penyelesaian untuk semua kejadian banjir di seluruh kawasan Kuala Lumpur. Hakikatnya, peranan utama terowong tersebut adalah untuk mengatasi kejadian banjir yang berlaku di kawasan yang terhad iaitu di pusat bandar Kuala Lumpur yang dikenali sebagai kawasan liputan SMART (Rajah 1). Terowong ini memastikan aliran air daripada Sungai Klang tidak membanjiri kawasan sasaran operasi iaitu 'jantung' Bandaraya Kuala Lumpur yang terletak di sekitar Masjid Jamek, Jalan Tun Perak, Dataran Merdeka, Kampung Baru, Jalan Munshi Abdullah, Kompleks Mahkamah Lama, Jalan Melaka, Jalan Tunku Abdul Rahman dan kawasan rendah di sekelilingnya (JPS, 2017; Samsuri et al., 2018). Di samping itu, projek ini bertujuan untuk mengurangkan kesesakan lalulintas di kawasan antara pusat Bandaraya Kuala Lumpur dan pintu masuk selatan di Sungai Besi (Pusat Kawalan SMART, 2016).

Terowong ini mempunyai peranan dwifungsi iaitu sebagai jalan alternatif ke ibu negara dan juga berperanan untuk mengalirkan air banjir ketika berlaku hujan lebat. Ia telah memenangi Anugerah Industri Pembinaan British (BCIA) 2008 kerana kecemerlangan dalam inovasi pembinaan dan kejuruteraan; dan Habitat Scroll of Honour Award 2011 daripada Pertubuhan Bangsa-Bangsa Bersatu (PBB). Terowong SMART dikawal selia oleh Pusat Kawalan SMART (SMART Control Centre/SCC), JPS. Komponen terowong terbahagi kepada dua iaitu komponen 
laluan air yang diurus oleh JPS dan komponen laluan jalan raya yang diurus oleh Lembaga Lebuhraya Malaysia (LLM).

Keunikan terowong ini adalah dua aras laluan trafik sejauh $3 \mathrm{~km}$ daripada keseluruhan terowong sepanjang $9.7 \mathrm{~km}$ bermula dari bulatan Kampung Pandan ke Lebuhraya Kuala Lumpur-Seremban yang terletak bersebelahan Lapangan Terbang TUDM di Sungai Besi. Ia dinobatkan sebagai terowong lencongan air yang terpanjang di Asia Tenggara dan kedua terpanjang di Asia (Pusat Kawalan SMART 2016). Tujuan utama terowong ini adalah untuk menyelesaikan masalah banjir kilat di Kuala Lumpur serta mengurangkan kesesakan lalulintas di sepanjang Jalan Sungai Besi dan di bawah jejambat Loke Yew di Pudu pada waktu puncak. Pada dasarnya, terowong ini mempunyai 2 dek laluan sehala untuk kenderaan manakala ruang paling bawah dikhaskan untuk laluan air (rujuk Rajah 2). Terowong ini bermula di Tasik Kampung Berembang berhampiran Sungai Klang di Ampang dan berakhir di Tasik Taman Desa berhampiran Sungai Kerayong di Salak Selatan.
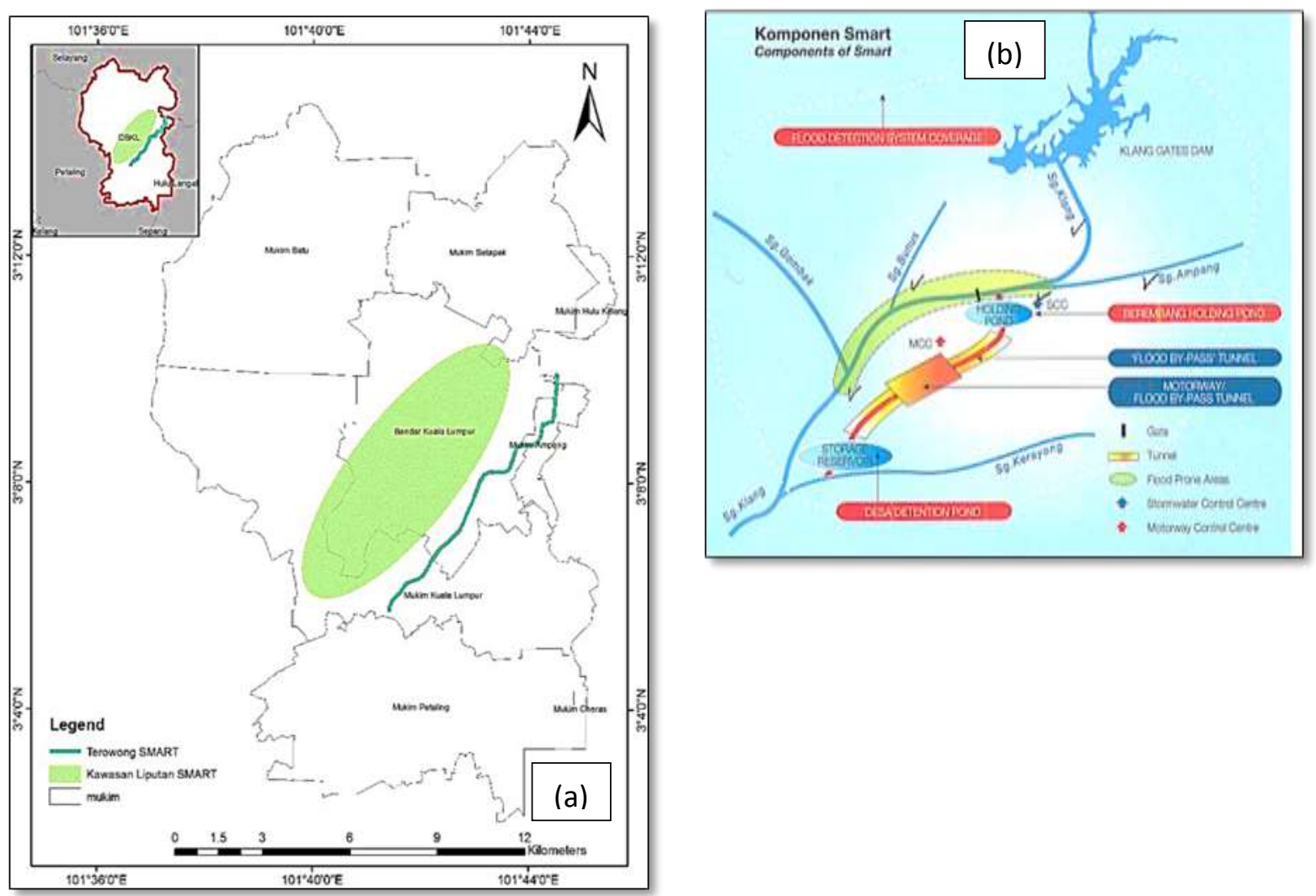

(Sumber: JPS \& DBKL 2017).

Rajah 1. Kawasan liputan Terowong SMART dan lokasi Terowong SMART.

Pengunaan Terowong SMART dihadkan untuk kegunaan kenderaan ringan yang mempunyai ketinggian maksimum kenderaan 2 meter serta had laju maksimum $60 \mathrm{~km} / \mathrm{j}$. Ia adalah dilarang untuk motosikal serta kenderaan berat seperti lori dan bas. Terowong tersebut dibuka secara rasmi pada 7 April 2007 (Pusat Kawalan SMART, 2016). Pusat Kawalan SMART (SMART SCC) di Kampung Berembang, Ampang menyelia operasi SMART 24 jam/7 hari. Manakala, Syarikat Mengurus Air Banjir dan Terowong Sdn. Bhd. (SMABT) di Pusat Kawalan Trafik 
SMART (SMART MCC) di Bulatan Kampung Pandan menyelia kawalan laluan trafik terowong (Pusat Kawalan SMART, 2016).

Terdapat empat mod seperti dalam Rajah 2 bagi Operasi SMART dan penerangan untuk setiap mod operasi boleh dirujuk pada Jadual 1. Dalam mod biasa, ketika cuaca cerah, SMART berperanan mengurangkan kesesakan trafik. Walau bagaimanapun, apabila berlaku hujan lebat dan aliran air berada pada tahap melebihi 70 meter padu sesaat $\left(\mathrm{m}^{3} / \mathrm{s}\right)$, mod akan bertukar secara automatik. Apabila aliran air melebihi $150\left(\mathrm{~m}^{3} / \mathrm{s}\right)$, atau tahap Prolonged Major Storm, SMART akan beroperasi pada mod keempat, menyebabkan terowong ditutup sepenuhnya kepada kenderaan bagi membolehkan terowong dilalui air banjir (Pusat Kawalan SMART, 2016).

Kebiasaannya, jika berlaku mod 4 (terowong ditutup sepenuhnya kepada kenderaan) ia akan mengambil masa selama 2 - 4 hari untuk kerja-kerja pembersihan dan pembaikan dilakukan sebelum boleh dibuka semula kepada lalulintas. Namun, setiap kali terowong ini ditutup, SMART mengalami kerugian hampir RM 1 juta kerana komponen elektrik dan dalamannya basah dan musnah akibat dimasukki air banjir (Yusop, 2011). Kos pengurusan akan meningkat setiap kali terowong SMART ditutup dan dibuka semula selepas banjir. Pada tahun 2012 sahaja terowong ini telah ditutup sebanyak tiga kali. Kadar bayaran yang tinggi diberikan kepada kontraktor untuk melakukan tugas pembersihan dengan cepat sedangkan mendapat notis dalam masa yang singkat antara faktor kos yang tinggi. Selain itu, kos yang mahal ini kerana air banjir yang laju berserta sampah termasuk serpihan-serpihan besar seperti perabot dan batang-batang pokok yang hanyut ke dalam terowong lalu merosakkan komponen-komponen mahal yang terdapat didalamnya (Lee, 2012).

Berdasarkan Jadual 2, mod (tahap) 4 pernah dicapai pada 4 September 2008, 21 Mei 2011, 7 Mac 2012, 2 Mei 2012 dan 26 November 2012 (Pusat Kawalan SMART, 2018) dan pada 23 Ogos 2013 dan 11 April 2013 (Humaira, 2013). Sekiranya terowong SMART tidak memainkan peranannya pada tarikh-tarikh tersebut, dianggap bahawa kejadian banjir kilat pasti akan berlaku di pusat bandar Kuala Lumpur. Yusop (2011) turut menyokong dalam penulisannya yang mana, terowong SMART telah terbukti berfungsi untuk memelihara ibu negara daripada lapan kejadian banjir besar sejak ia diaktifkan. Ternyata, pembinaan terowong ini dilihat sebagai satu inisiatif yang besar untuk mengurangkan kejadian-kejadian banjir kilat di pusat Bandaraya Kuala Lumpur. Pendapat ini turut dipersetujui oleh Samsuri et al. (2018); Nuhu dan Maimunah (2015) serta Nuhu dan Manimunah (2017) dan Nuhu dan Ali (2017) dalam kajian mereka. Namun bukti empirikal bagi menyokong kesimpulan tersebut tidak kukuh. 


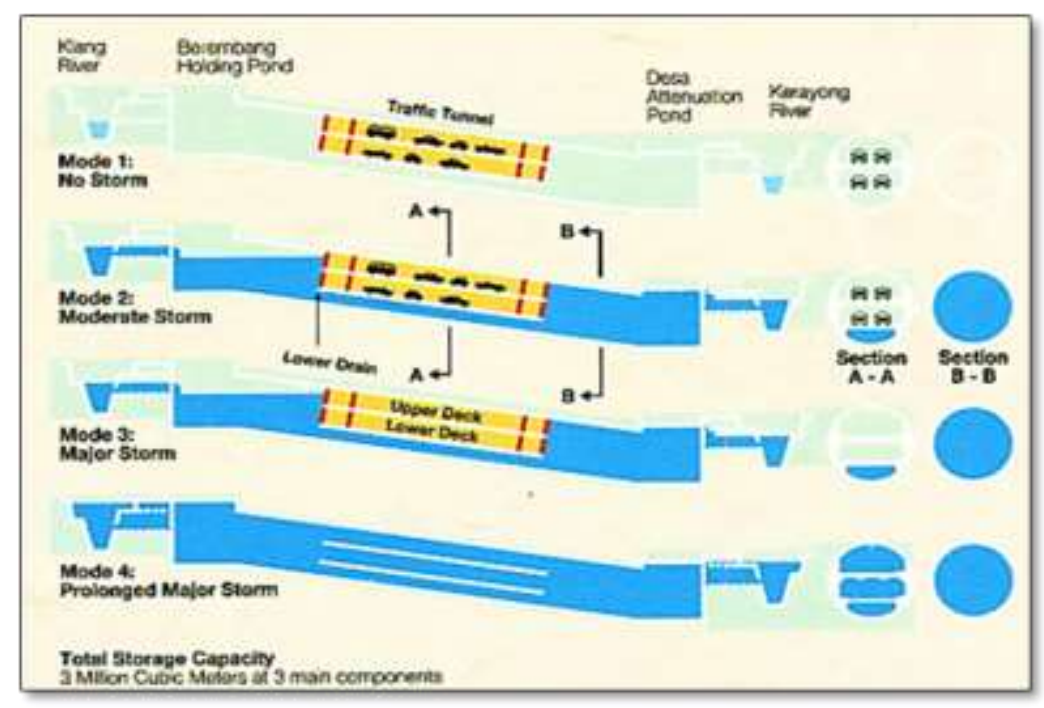

Sumber: JPS 2017

Rajah 2. Mod operasi Terowong SMART.

Jadual 1. Penerangan mod Terowong SMART.

\begin{tabular}{ll}
\hline Mod & Penerangan \\
\hline 1 & Ketika cuaca biasa atau hujan renyai-renyai, terowong dibuka untuk lalulintas keluar dan \\
& masuk dari Kuala Lumpur. \\
\hline 2 & Sekiranya hujan turun dan sukatan di stesen hidrologi (L4) yang terletak di pertemuan Sungai \\
& Klang/Sungai Ampang mencatatkan bacaan $70 \mathrm{~m}^{3} / \mathrm{s}-150 \mathrm{~m}^{3} / \mathrm{s}$. Air akan dilalukan di bahagian \\
& bawah (lower drain) terowong. Hanya $50 \mathrm{~m}^{3} / \mathrm{s}$ air akan dibenarkan untuk dialirkan ke Pusat \\
& Bandaraya Kuala Lumpur tetapi terowong trafik masih dibuka untuk lalulintas. \\
\hline 3 & Jika hujan lebat turun dan model ramalan banjir meramalkan kadaralir di L4 melebihi 150 \\
& $\mathrm{m}^{3} / \mathrm{s}$. Terowong akan dihalang daripada dilalui oleh kenderaan. Jika hujan lebat yang turun \\
& hanya sebentar atau atas sebab teknikal lain yang tertentu maka terowong akan dibuka semula \\
& bagi lalulintas selepas 2 - 8 jam ditutup. \\
\hline 4 & Selepas 1 - 2 jam amaran Mod 3 dikeluarkan dan sekiranya hujan lebat masih berpanjangan \\
& terowong trafik ditutup sepenuhnya dan akan digunakan untuk laluan air banjir dan akan \\
& dibuka semula hanya selepas 4 hari ia ditutup. \\
\hline
\end{tabular}

Sumber: JPS 2018

Jadual 2. Tarikh-tarikh dan mod-mod operasi Terowong SMART dari April 2007 hingga Mei 2018

\begin{tabular}{l|ccccc}
\hline Tahun & Mod 2 & Mod 2B & Mod 3 & Mod 4 & Jumlah \\
\hline 2007 & 13 & 0 & 2 & 0 & 15 \\
2008 & 30 & 0 & 21 & 1 & 52 \\
2009 & 20 & 0 & 13 & 0 & 33 \\
2010 & 11 & 0 & 14 & 0 & 25 \\
2011 & 21 & 0 & 19 & 1 & 41 \\
2012 & 25 & 0 & 8 & 3 & 36 \\
2013 & 21 & 4 & 2 & 0 & 27 \\
2014 & 24 & 0 & 2 & 0 & 26
\end{tabular}


GEOGRAFIA Online ${ }^{\mathrm{TM}}$ Malaysian Journal of Society and Space 16 issue 3 (184-200)

(C) 2020, e-ISSN 2682-7727 https://doi.org/10.17576/geo-2020-1603-14

\begin{tabular}{l|ccccc}
2015 & 19 & 2 & 0 & 0 & 21 \\
2016 & 15 & 0 & 0 & 0 & 15 \\
2017 & 32 & 2 & 1 & 0 & 35 \\
2018 & 9 & 1 & 0 & 0 & 15 \\
Jumlah & 240 & 9 & 82 & 5 & 336 \\
\hline
\end{tabular}

Sumber: JPS 2018

\section{Metodologi}

Aliran kerja kajian ini merangkumi (i) pengumpulan dan penyediaan data melalui analisis dokumen, (ii) pembangunan inventori banjir, (iii) analisis trend dan, (iv) analisis spatial. Carta aliran kerja ini dapat dirujuk melalui Rajah 3.

Analisis dokumen adalah melalui proses pengumpulan dan penyediaan data dari sumber maklumat yang pelbagai meliputi laporan teknikal daripada jabatan yang berkaitan. Ini termasuk Dewan Bandaraya Kuala Lumpur (DBKL), Jabatan Pengairan dan Saliran (JPS) dan juga beberapa domain terbuka merangkumi laman sesawang, pangkalan data arkib akhbar tempatan dan databes bencana terbuka. Rekod kejadian banjir kilat diperolehi daripada JPS untuk tahun 1984-2012 manakala dari DBKL maklumat kejadian diperolehi dari tahun 2008-2017. Rekod ini ditambahbaik dan disokong dengan maklumat tambahan melalui sumber dari domain terbuka. Kawasan liputan Terowong SMART dan lokasi kawasan banjir yang berfrekuensi tinggi turut didapati daripada DBKL. Data hujan harian diperolehi dari Jabatan Meteorologi Malaysia (JMM) dari 2007-2018 manakala maklumat stesen hujan pula didapati melalui JPS dan DBKL. Kesemua maklumat ini disemak untuk mengelakkan pertindanan dan disusun mengikut keperluan dalam pembangunan inventori banjir.

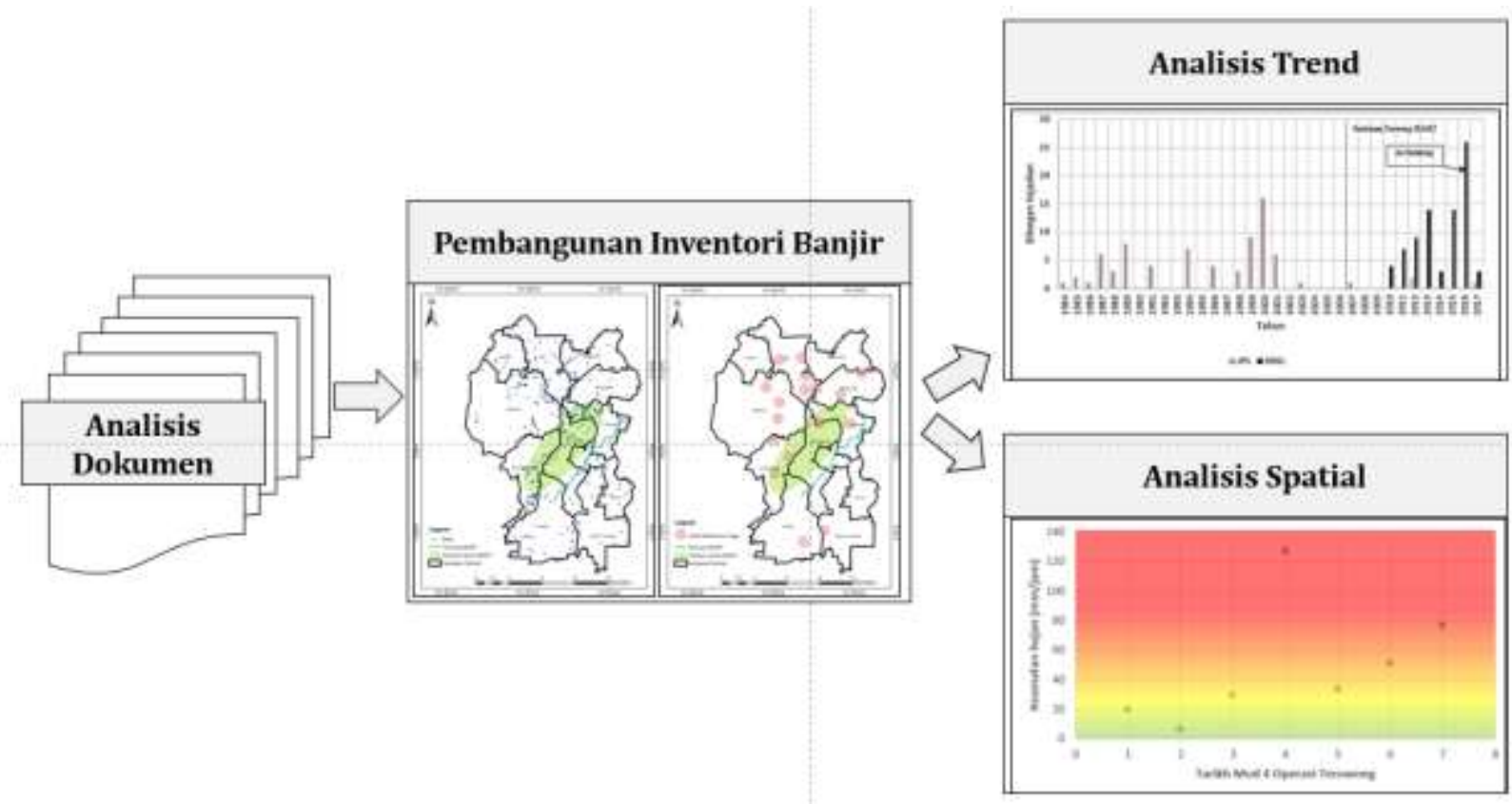

Rajah 3. Carta alir kajian 
Pembangunan inventori banjir adalah melalui proses merekod data kejadian dan lokasi dalam bentuk jadual dan disusun mengikut tahun, lokasi, jumlah kerosakan, bilangan mangsa dan ketinggian aras air dari tahun 1984 sehingga 2017. Setiap maklumat ini kemudiannya diplotkan ke dalam perisian Google Earth Pro. Data dari Google Earth Pro dalam format .kmz ini kemudiannya dipindahkan ke perisian ArcGIS dalam bentuk .kml dan dipaparkan dalam satu shapefiles layer. Proses seterusnya ialah membetulkan unjuran data ke unjuran WGS84. Inventori yang telah dibangunkan dieksport ke dalam sekitaran ArcGIS untuk membentuk jadual attribut. Seterusnya lokasi liputan SMART seperti dipetakan dalam Rajah 4 bersama dengan kawasan hotspot banjir. Lokasi ini merupakan kawasan yang kerap mengalami kejadian banjir selepas hujan berdasarkan pemerhatian oleh pihak DBKL.

Analisis trend melalui kaedah stastik deskriptif dijalankan pada rekod inventori untuk mengenalpasti taburan kejadian banjir dari tahun 1984 sehingga 2017. Dengan menggunakan aplikasi statistik pada Microsoft excel, pola kejadian banjir dapat dikenalpasti pada situasi fasa sebelum (tahun 1984-2007) dan fasa selepas pembinaan terowong SMART (tahun 2008-2017). Pola taburan kejadian banjir di Kuala Lumpur dalam tempoh ini telah divisualisasikan di dalam bentuk peta. Pengelasan tempoh fasa pembinaan terowong SMART ini penting untuk memantau keberkesanan sistem SMART secara empirikal dalam menangani masalah banjir yang sering berlaku di Kuala Lumpur.

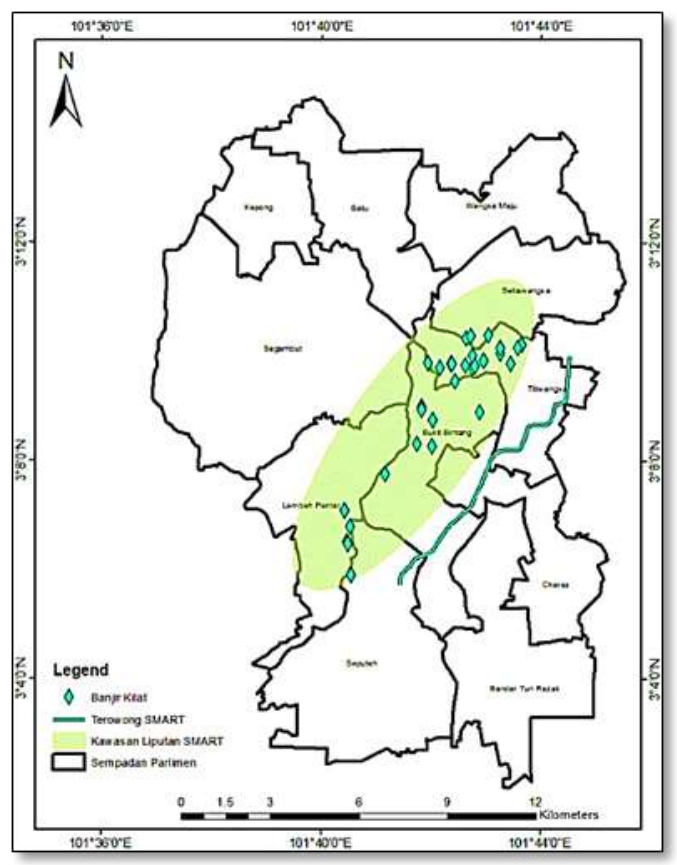

(a)

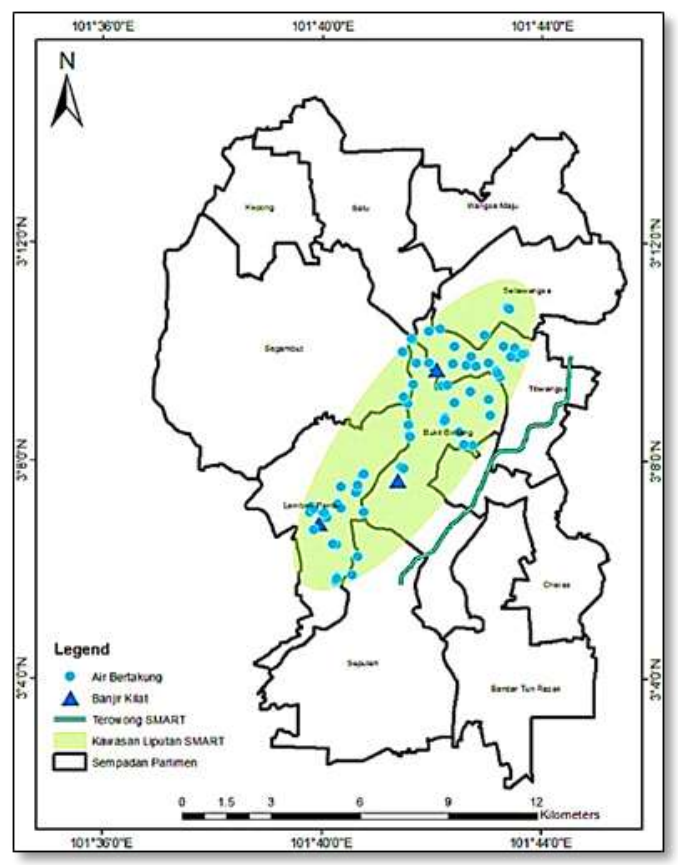

(b)

Sumber: JPS, DBKL, \& SEADPRI-UKM 2008-2017

Rajah 4. (a) Peta menunjukkan kejadian banjir kilat sebelum pembinaan Terowong SMART manakala,

(b) Peta menunjukkan kejadian banjir kilat dan air bertakung selepas pembinaan Terowong SMART.

Analisis spatial dilakukan melalui kaedah poligon Thiessen. Analisis ini adalah untuk mengenalpasti hubungan mod operasi terowong dengan intensiti hujan bagi mengesahkan samada parameter ini mewakili kemungkinan kejadian banjir kilat di Kuala Lumpur. Kaedah poligon Thiessen adalah metodologi yang lazim digunakan untuk mengira purata curahan hujan 
bagi kawasan tadahan berdasarkan bacaan tolok hujan. Kaedah Thiessen didasarkan pada andaian bahawa jumlah air hujan yang diukur di mana-mana stesen boleh digunakan separuh ke stesen seterusnya dalam sebarang arah, yang bermaksud bahawa untuk mana-mana curah hujan titik sama dengan hujan yang diperhatikan pada tolok terdekat. Berat pengukur hujan dikira oleh kawasan relatifnya, yang dianggarkan dengan rangkaian poligon Thiessen. Poligon terbentuk daripada bisektor tegak lurus garisan yang menyambung stesen berdekatan. Kawasan setiap poligon digunakan untuk menimbang jumlah hujan stesen di pusat poligon (Schumann, 1998).

\section{Hasil dan Perbincangan}

Berdasarkan analisis dokumen yang dijalankan, kajian ini mendapati capaian maklumat kejadian banjir kilat adalah sukar dan terhad daripada jabatan yang berkaitan. Kajian menggunakan maklumat tambahan melalui sumber dari domain terbuka sebagai alternatif untuk menambahbaik rekod kejadian banjir kilat di Kuala Lumpur. Berdasarkan analisis ini, rekod kejadian yang diperolehi dari tahun 1984 sehingga 2017 adalah meliputi keseluruhan Wilayah Persekutuan Kuala Lumpur. Banyak kejadian berlaku di kawasan jalanraya dan premis perniagaan yang berdekatan. Situasi ini menjelaskan bahawa akses kemudahan penting seperti pengangkutan dan sumber pendapatan penghuni terjejas. Kajian turut mendapati sebanyak 157 kejadian telah berlaku di dalam kawasan litupan SMART yang mana banjir kilat dan air bertakung merupakan kejadian yang lazim berlaku di Kuala Lumpur.

Melalui inventori yang dibangunkan, taburan spatial kejadian banjir kilat pula dilihat lebih terkumpul di bahagian kanan atas kawasan liputan SMART di antara aliran Sungai Bunus dan Sungai Klang seperti dalam Rajah 4a. Sementara itu, taburan air bertakung adalah lebih berselerak merangkumi seluruh kawasan liputan SMART. Terdapat empat kawasan yang kerap mengalami banjir kilat (hotspot) turut berada di kawasan liputan Terowong SMART iaitu di i) Pusat Kegiatan Guru Keramat, Jalan Semarak; ii) Jalan Ampang off Jalan Sultan Ismail; iii) Jalan Kemuja, Bangsar; dan iv) Lebuhraya Persekutuan, Bangsar South City (Rajah 5). Namun, data telah menunjukkan bahawa Terowong SMART telah berjaya mengalihkan $280 \mathrm{~m}^{3}$ air banjir dari bahagian atas sungai ke kolam tadahan Kampung Berembang Klang melebihi 70 kali dengan kapasiti $600,000 \mathrm{~m}^{3}$. Sungguhpun terdapat kawasan yang kerap mengalami banjir dalam liputan SMART, fungsi terowong telah menyelamatkan Kuala Lumpur daripada mudarat. 


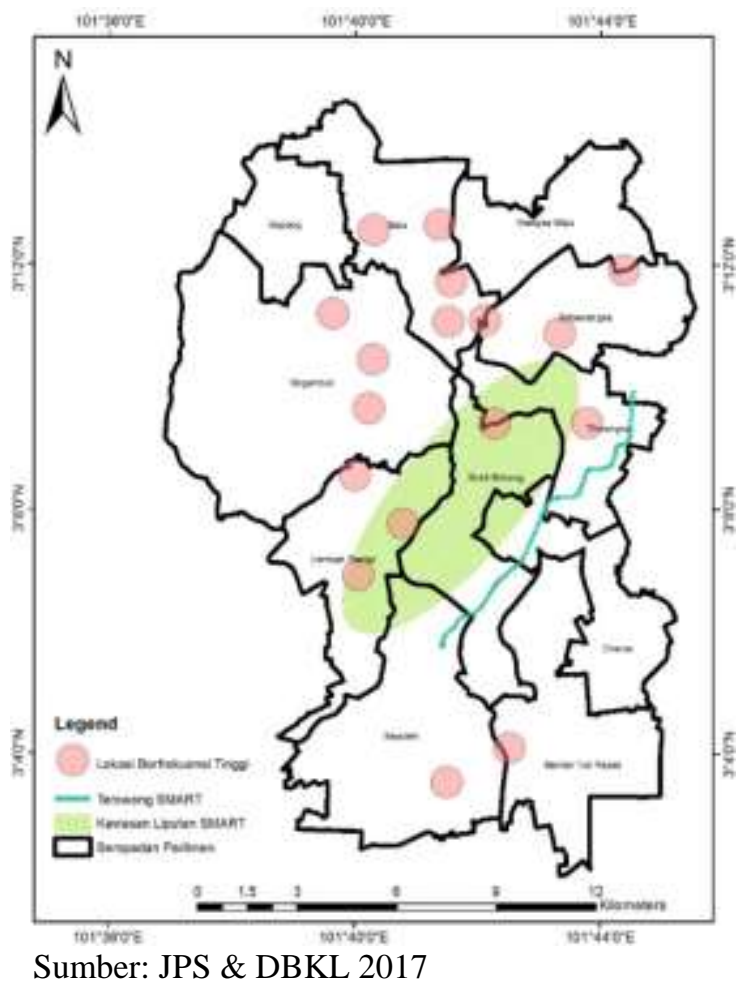

Rajah 5. Kawasan liputan Terowong SMART dan lokasi kerap mengalami banjir

Terowong SMART telah mula beroperasi pada tahun 2007. Justeru, analisis trend telah mengelaskan pengukuran kepada fasa sebelum dan selepas pembinaan terowong seperti yang ditunjukkan dalam histogram di Rajah 6. Pada fasa sebelum pembinaan Terowong SMART, jumlah kejadian banjir kilat adalah sebanyak 74 manakala selepas 2007, kajian mendapati bilangan banjir kilat adalah menurun kepada tujuh kejadian. Sebaliknya, kejadian air bertakung lebih kerap pula berlaku selepas tahun 2010. Sehingga 2017, kajian merekodkan lebih kurang 83 kejadian air bertakung dalam awasan liputan SMART di bandaraya ini. Dalam konteks tempatan, DBKL menerangkan kejadian air bertakung ini ialah kejadian air naik secara mendadak di atas jalan dan akan surut semula dalam masa yang sangat singkat iaitu kurang daripada sejam. Berdasarkan penemuan ini, kajian berpendapat bahawa terowong SMART telah memainkan peranannya dengan baik dalam menangani isu banjir kilat. Fenomena air bertakung yang muncul pada fasa selepas terowong SMART dibina dilihat sebagai impak daripada aktiviti perbandaran pesat yang berlaku di Kuala Lumpur. Banyak bandar kontemporari terdedah kepada air bertakung dan risiko berkaitan dijangka meningkat seiring dengan kejadian iklim ekstrim, peningkatan penduduk bandar dan usia infrastruktur yang sedia ada (Hossain et al., 2015). Dalam usaha mengatasi fenomena air bertakung, penyelengaraan saluran air dan longkang di kawasan yang kerap banjir (hostpot) perlu ditingkatkan. Selain itu, kaedah semula jadi juga boleh dipertimbangkan seperti membuat lubang berongga atau lubang di dalam tanah yang penuh dengan batuan berongga vertikal. Batuan berfungsi untuk menyerap air hujan dan melepaskannya secara perlahan-lahan sebagai air tanah. Mewujudkan lebih banyak kawasan rekreasi yang beralun dan yang diliputi rumput yang bertindak sebagai kawasan tadahan air hujan sementara turut dapat mengurangkan risiko air bertakung. Aplikasi sistem paip berongga iaitu satu sistem yang hampir sama dengan kaedah lubang berongga boleh juga digunapakai. 
Masalah air bertakung harus ditangani secara holistik di mana perancangan dan pembangunan bandar berasaskan kepada pendekatan ekologi. Pendekatan ini yang dinamakan pembangunan bandar sponge (sponge city development) telah menjadi dasar kebangsaan di China bagi menangani masalah air bertakung akibat daripada banjir pluvial (Ma et al., 2020). Kesesuaian pendekatan bandar sponge untuk Kuala Lumpur perlu dikaji memandangkan masalah berkaitan air bertakung dijangka bertambah serius dengan cuaca ekstrem yang dijangka akibat daripada perubahan iklim.

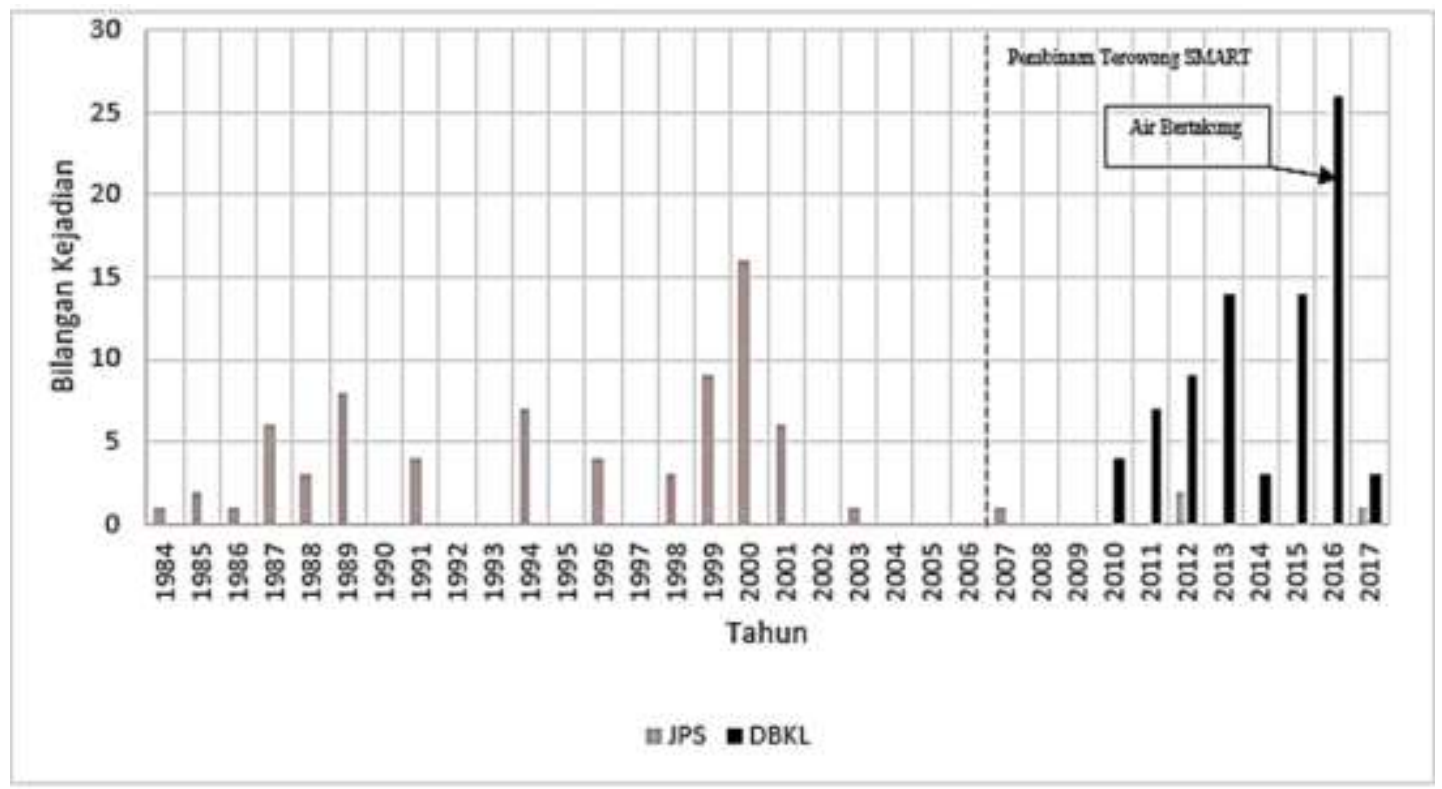

Sumber: JPS, DBKL, \& SEADPRI-UKM

Rajah 6. Bilangan kejadian banjir kilat di Kuala Lumpur dari tahun 1984-2017.

Stesen hujan yang dikenalpasti merupakan gabungan stesen hujan JPS dan Unit Kawalan SMART kerana bacaan stesen hujan JPS telah menjalani proses kalibrasi berbanding stesen hujan dari Unit Kawalan SMART. Kajian ini tidak mempertimbangkan stesen hujan dari Jabatan Meteorologi Malaysia kerana lokasi stesen berada diluar kawasan kajian. Stesen-stesen tersebut adalah stesen hujan Kampung Berembang (a), Keramat, stesen hujan Sungai Bunus, Jalan Tun Razak (b), stesen hujan Bulatan Kampung Pandan, Jalan Tun Razak (c) dan stesen hujan Ibu Pejabat JPS Wilayah Persekutuan (d). Berdasarkan hasil yang ditunjukan di Rajah 7, secara kasarnya kajian berpendapat, wujud hubungan positif antara operasi mod 4 diaktifkan dengan jumlah keamatan hujan. Inferens ini disokong dengan senario seperti dalam Rajah 7a dan 7b, pada 07 Mac 2012 yang mana bacaan keamatan hujan pada kedua-dua stesen adalah sangat lebat yang menyebabkan mod 4 diaktifkan. Dalam senario lain, keamatan hujan pada 23 Ogos 2013 adalah sederhana pada Rajah 7(a), 7(b) dan 7(c) sebaliknya pada 7(d), keamatan hujan adalah sangat lebat. Hubungan positif kedua-dua parameter wujud apabila sekurang-kurangnya satu stesen menunjukkan bacaan keamatan hujan yang relevan untuk mengaktifkan mod 4 operasi terowong.

Majoriti mod 4 operasi terowong diaktifkan pada waktu petang dari jam 3 petang hingga 6 petang. Hanya pada 23 Ogos 2013 sahaja operasi mod 4 diaktifkan pada waktu pagi sekitar jam 5 pagi - 7 pagi. Kajian mendapati waktu-waktu mod 4 diaktifkan adalah waktu kemuncak (peak 
hours) kesesakan lalu lintas. Sekiranya mod 4 tidak aktifkan pada masa yang tepat, Kuala Lumpur mungkin akan mengalami banjir kilat atau air bertakung.

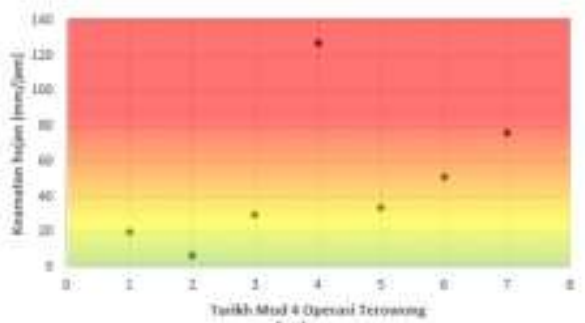

(a)

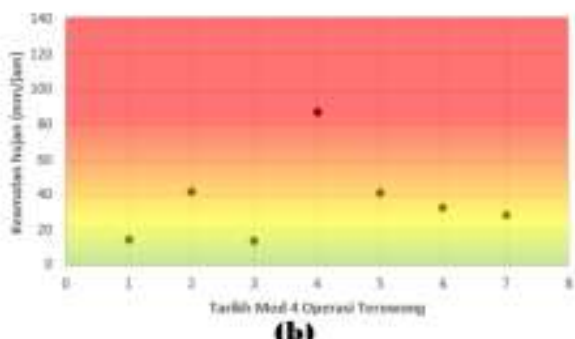

(b)

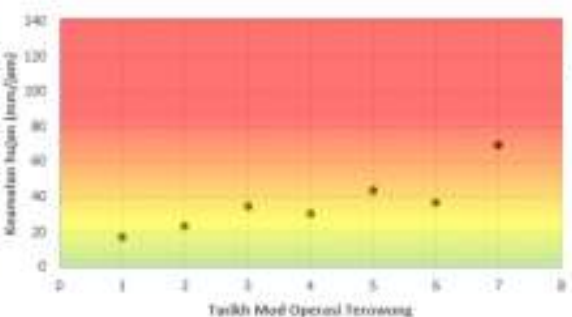

(e)

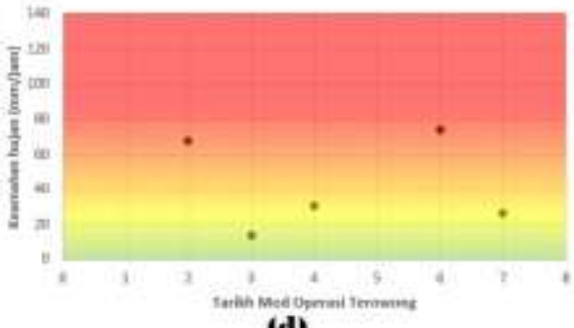

(d)

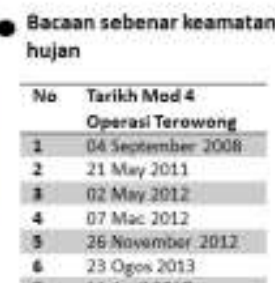

$7 \quad 11$ Agril 2017

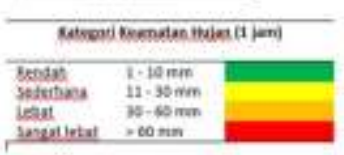

Sumber: JPS \& http://publicinfobanjir.water.gov.my/

Rajah 7. Jadual Keamatan Hujan bagi Stesen Hujan (a) Kampung Berembang, Keramat, (b) Stesen Hujan Sungai Bunus, Jalan Tun Razak, (c) Stesen Hujan Bulatan Kampung Pandan, Jalan Tun Razak dan (d) Stesen Hujan Ibu Pejabat JPS Wilayah Persekutuan.

\section{Kesimpulan}

Terowong SMART telah memainkan peranan yang penting untuk menghalang lebih banyak kejadian banjir kilat daripada berlaku di Bandaraya Kuala Lumpur. Terdapat hubungan positif di antara mod operasi Terowong dengan intensiti hujan di kawasan liputan SMART Kuala Lumpur. Mod operasi diaktifkan apabila berlaku hujan lebat dan sangat lebat pada sekurang-kurangnya satu stesen hujan yang berdekatan di kawan liputan SMART. Hanya 7 kejadian banjir kilat telah direkodkan sejak Terowong SMART mula beroperasi pada tahun 2017. Namun, kejadian air bertakung telah muncul dengan kerap selepas terowong ini dibina. Di antara 2010 dan 2017, sebanyak 83 kejadian air bertakung telah dilaporkan. Saranan kajian adalah untuk mengkaji kesesuaian pendekatan bandar sponge untuk Kuala Lumpur memandangkan masalah berkaitan air bertakung dijangka bertambah serius di masa hadapan akibat daripada cuaca ekstrem yang disebabkan oleh perubahan iklim.

\section{Penghargaan}

Penyelidikan ini merupakan sebahagian daripada projek yang bertajuk Disaster Resilient Cities: Forecasting Local Level Climate Extremes and Physical Hazards for Kuala Lumpur (XX-2017002) yang disokong oleh Research and Innovation Bridges Programme of the Newton-Ungku 
GEOGRAFIA Online ${ }^{\mathrm{TM}}$ Malaysian Journal of Society and Space 16 issue 3 (184-200)

(C) 2020, e-ISSN 2682-7727 https://doi.org/10.17576/geo-2020-1603-14

Omar Fund yang ditadbir oleh Malaysian Industry-Government Group for High Technology (MIGHT) dan Innovate UK.

\section{Rujukan}

Abdullah, K. (2004). Kuala Lumpur: Re-Engineering A Flooded Confluence. Fourteenth Professor Chin Fung Kee Memorial Lecture.

Aziz, I. H. (2013). KL, Selangor Dilanda Banjir Kilat. Utusan Malaysia Online. Retrieved from http://ww1.utusan.com.my/utusan/Dalam_Negeri/20131011/dn_09/KL-Selangor-dilandabanjir-kilat.

Baharudin, Y., Maimon, A. \& Salmijah, S. (2012). Beberapa Peristiwa Banjir Besar dan Tindakan Mengawal Banjir di Malaysia: Banjir Besar Johor. Bangi: Universiti Kebangsaan Malaysia.

Bates, B. C., Kundzewicz, S., Wu, S. \& J.P. (2008). IPCC Technical Paper on Climate Change and Water. Cambridge, United Kingdom and New York: IPCC, Cambridge University Press.

Bertilsson, L., Wiklund, K., de Moura, I., Tebaldi, O.M. Rezende, A.P. Veról, M.G. Miguez. (2019). Urban flood resilience-a multi-criteria index to integrate flood resilience into urban planning. J. Hydrol., 573, 970-982.

Bhuiyan, T. R., Hasan Reza, M. I., Choy, E. A. \& Pereira, J. J. (2018). Direct impact of flash floods in Kuala Lumpur City: Secondary data-based analysis. ASM Science Journal, 11(3), 145-157.

Bhuiyan, T. R., Reza, M. I. H., Choy, E. A. \& Pereira, J. J. (2018). Facts and trends of urban exposure to flash flood: A case of kuala lumpur city. Community, Environment and Disaster Risk Management 20, 79-90. doi:10.1108/S2040-726220180000020016

Buletin Darulnaim. (2015). Januari-Februari 2015. Bil 163. ISSN 1311-6891

Buletin Mutiara. (2017). 16 Disember 2017. Perutusan Ketua Menteri Pulau Pinang, Lim Guan Eng pada 16 Disember 2017 Sempena Upacara Pemberian Wang Bantuan Kepada Mangsa Bencana Banjir Dan Ribut 5 November 2017

Bulti, D. T. \& Abebe, B. G. (2020). A review of flood modelling methods for urban pluvial flood application. Modeling earth systems and environment 6, 1293-1302.

Chan, N. W. (1995). Flood disaster management in Malaysia: An evaluation of the effectiveness of government resettlement schemes. Disaster Prevention and Management: An International Journal 4(4), 22-29. doi:10.1108/09653569510093405

Chong Wing, C. (2016). Managing Flood Problems. Buletin Ingenieur 38-43.

Dayon, G., Boé, J., Martin, É. \& Gailhard, J. (2018). Impacts of climate change on the hydrological cycle over France and associated uncertainties. Comptes Rendus Geoscience. doi:10.1016/j.crte.2018.03.001.

Diya, S. G., Gasim, M. B., Toriman, M. E. \& Abdullahi, M. G. (2014). Floods in Malaysia: Historical Reviews, Causes, Effects and Mtigations Approach. International Journal of Interdisciplinary Research and Innovations 2(4), 59-65. doi:10.5897/AJBx10.009.

Harisaweni, Y. Z., \& Yusof, F. (2016). The use of BLRP model for disaggregating daily rainfall affected by monsoon in Peninsular Malaysia. Sains Malaysiana 45(1), 87-97.

Hashim, N. \& Ahmad, A. H. (2007). Tepubina bandar: Isu dan kaitannya dengan kesihatan ekosistem lembangan saliran. Geografia-Malaysian Journal of Society and Space, 3(1), 
GEOGRAFIA Online ${ }^{\mathrm{TM}}$ Malaysian Journal of Society and Space 16 issue 3 (184-200)

(C) 2020, e-ISSN 2682-7727 https://doi.org/10.17576/geo-2020-1603-14

20-34.

Hossain, M. A. \& Huq, M. E. (2015). Vulnerability Framework for Flood Disaster Management. The Journal of Geo-Environment 11, 51-67.

Humaira, A. (2013). Elak banjir di KL, terowong Lebuhraya SMART ditutup. Berita Harian. Retrieved from https://www.bharian.com.my/berita/wilayah /12/641273/elak-banjir-di-klterowong-lebuhraya-smart-ditutup

Ishak, A. M., Redzuan, N., Kalken, T. V. A. N. \& Brown, K. (2017). Malaysian National Water Balance System ( Nawabs ) for Improved River Basin Management: Case Study in the Muda River Basin. E-proceedings of the 37th IAHR World Congress August 13 - 18, 2017, Kuala Lumpur, Malaysia MALAYSIAN 6865(1), 4421-4430.

Jamaludin, S., Mohd Deni, S., Wan Zin, W. Z. \& Abdul Aziz, J. (2010). Trends in Peninsular Malaysia Rainfall Data During the Southwest Monsoon and Northeast Monsoon Seasons: 1975-2004. Sains Malaysiana 39(4), 533-542. doi:10.1016/j.healthplace.2008.09.010

JPS. (1999). Laporan banjir kilat di Lembangan Sungai Kelang Tahun 1999. Kuala Lumpur: Bahagian Hidrologi, Jabatan Pengairan dan Saliran Malaysia.

JPS. (2000). Laporan Banjir di Pahang Tahun 2000. Kuala Lumpur: Jabatan Pengairan dan Saliran.

JPS. (2017). Laporan Banjir Tahunan Bagi Tahun 2016/2017. Jabatan Pengairan dan Saliran

JPS. (2018). Laporan Terowong SMART 2018. Jabatan Pengairan dan Saliran

Kong, Y. Y., Noor Azima, B., \& Yew, K. (2010). A study on the urban flooding.

Lwe, R. \& Arnbjerg-Nielsen,K. (2020). Urban pluvial flood risk assessment-data resolution and spatial scale when developing screening approaches on the microscale. Natural hazards and earth system science (20), 981-997.

Potter, K. \& Vilcan, T. (2020). Managing urban flood resilience through the English planning system: insights from the SuDS-face. Philosophical Transactions of The Royal Society A Mathematical Physical and Engineering Sciences 378(2168), 0190206, doi:10.1098/rsta.2019.0206

Lee, R. (2012). Penutupan SMART Bawa Kepada Peningkatan Kos Operasi. www.mstar.com.my. Retrieved from https://www.mstar.com.my/lokal/semasa/2012/11/30/penutupan-smart-bawa-kepadapeningkatan-kos-operasi

Ma, Y., Jiang, Y. \& Swallow, S. (2020). China's sponge city development for urban water resilience and sustainability: A policy discussion. Science of the Total Environment $729,139078$.

McGrane, S. J. (2016). Impacts of urbanisation on hydrological and water quality dynamics, and urban water management: a review. Hydrological Sciences Journal 61(13), 2295-2311. doi:10.1080/02626667.2015.1128084

Mohamad Khairul Nizam, M. A. C., Mohd Wafig, I., Muhammad Farid, A. F., Mohamad Taufiq, M., Muhammad Amirul Afham, H., Mohamad Nurul Hafizi, M. N., \& Edie Azhar, R. (2014). Stormwater Management And Road Tunnel (SMART) Project In Kuala Lumpur, Malaysia. Universiti Kuala Lumpur. Universiti Kuala Lumpur.

Mohamad Yusoff, I., Ramli, A., Mhd Alkasirah, N. A. \& Mohd Nasir, N. (2018). Exploring the managing of flood disaster: A Malaysian perspective. Geografia Malaysian Journal of Society and Space 14(3), 24-36. doi:10.17576/geo-2018-1403-03

Noorazuan, M.H.(2006). Urban hydrological changes in the Sankey Brook catchment. Unpublished PhD thesis. Manchester: University of Manchester 
GEOGRAFIA Online ${ }^{\mathrm{TM}}$ Malaysian Journal of Society and Space 16 issue 3 (184-200)

(C) 2020, e-ISSN 2682-7727 https://doi.org/10.17576/geo-2020-1603-14

Nordmark, A. (2002). Overview on survey of water installations underground: underground water-conveyance and storage facilities. Tunnelling and Underground Space Technology 17, 63-178

Nuhu, I. \& Maimunah, A. (2015). A Relationship between Flood Occurrences and the Maintenance Works of SMART Tunnel, Kuala Lumpur, Malaysia. International Journal of Research and Review 2(7), 434-449.

Nuhu, I. \& Ali, M. (2017). A Thematic Analysis on the Causes of Flood Disaster and Roles of Smart Tunnel in Flood Disaster Management in Kuala Lumpur Malaysia. International Journal of Research and Review 2(10), 624-640.

Nuhu, I. \& Maimunah, A.(2017). A Review of the Literature on the Roles and Features of SMART Tunnel. Kuala Lumpur, Malaysia. International Journal of Research and Review 2(7), 465-475.

Potter, K. \& Vilcan, T. 2020. Managing urban flood resilience through the English planning system: insights from the SuDS-face. Philosophical Transactions of The Royal Society A Mathematical Physical and Engineering Sciences 378(2168):20190206. doi:10.1098/rsta.2019.0206

Pusat Kawalan SMART. (2016). What is SMART? SMART Motorway Tunnel. Retrieved from http://smarttunnel.com.my/smart/what-is-smart/ [10 November 2017].

Pusat Kawalan SMART. (2018). Laporan Pusat Kawalan SMART 2018, Jabatan Pengairan dan Saliran

Ribeiro, P. J. G., \& Goncalves, L. A. P. J. (2019). Urban resilience: A conceptual framework. Sustainable Cities and Societies 50, 101625

Rubinato, M., Nichols, A., Peng, Y., Zhang, J., Lashford, C., Cai, Y., Lin, P. \& Tait, S. (2019). Water and river flooding: Comparison of flood risk management approaches in the UK and China and assessment of future knowledges needs. Water Science and Engineering Vol 4 (12), 274-283.

Samsuri, N., Abu Bakar, R. \& Unjah, T. (2018). Flash Flood Impact in Kuala Lumpur-Approach Review and Way Forward. International Journal of the Malay World and Civilisation 6 (Special Issue 1), 69-76. doi:https://doi.org/10.17576/jatma-2018-06SI1-10

Shamsul M. S. (2017). Banjir di Penang kian buruk. Harian Metro

Sani, G. D., Muhd, B. G., Mohd, E. T. \& Musa, G. A. (2014). Floods In Malaysia: Historical Reviews, Causes, Effects and Mitigations Approach. International Journal of Interdisciplinary Research and Innovations 2(4), 59-65.

Schumann, A. H. (1998). Encyclopedia of Hydrology and Lakes, 48-649. Kluwer Academic Publishers. doi:https://doi.org/10.1007/1-4020-4497-6_220

Tiza, M. T., Iorver, V. T. \& Iortyom, E. T. (2016). The Effects of Poor Drainage System on Road Pavement: A Review. International Journal for Innovative Research in Multidisciplinary Field 2(8).

Tunnel. (2012). Long Term Flood Prevention in Chaophaya Basin, Thailand. Tunnel 3/2012

Van Der Sterren, M., Shrestha, S. \& Rahman, A. (2007). A Risk Assessment of Ponding Using Grated Drainage System In Urban Areas of Western Sydney in Australia. World Environmental and Water Resources Congress: Restoring Our Natural Habitat, 1-8. doi:https://doi.org/10.1061/40927(243)569

Ward, P. J., Jongman, B., Aerts, J. C. J. H., Bates, P. D., Botzen, W. J. W., DIaz Loaiza, A., \& Hallegatte, S.(2017). A global framework for future costs and benefits of river-flood protection in urban areas. Nature Climate Change 7 (9), 642-646. 
doi: $10.1038 /$ nclimate 3350

Yusop, S. H. (2011). Elak 8 banjir besar limpahi KL. Berita Harian. Retrieved from http://www.bharian.com.my/articles/E...ahiKL/Article/

Zainab, H., Nor Hisham, M. G. \& Larry Charles, S. J. (2013). SMART Saves Kuala Lumpur City Centre from Innundation. The Journal of Water Resources Management 1(2), 17-34. Zolbert \& Alex. (2012). How giant tunnels protect Tokyo from flood threat. CNN. Published November 1, 2012. 